Agnieszka Wiciak

Muzeum Historii LGBTQIA

Klub Historyczny LGBTQIA FEM Fundacji Q

\title{
Polskie muzeum LGBTQIA
}

Stworzenie wirtualnego muzeum jest związane z istniejącym archiwum Klubu Historycznego LGBTQIA ${ }^{1}$ FEM, które jest częścią Fundacji Q. Pierwotnie, w roku 2017, powstał nieformalny, prywatny i niezwiązany z żadną organizacją Klub Historyczny, czyli tzw. grupa kolekcjonerska. Powołany został przez dwie osoby: Agnieszkę Wiciak oraz Kamila Prykowskiego, a jego głównym zadaniem było zbieranie materiałów archiwalnych dotyczących społeczności LGBTQIA. Jednakże ze względu na fakt, że grupa nieformalna ma swoje ograniczenia związane na przykład ze staraniem się o fundusze oraz możliwościami i zakresem działania, już po roku powołana została Fundacja Q. Zgodnie ze statutem jej celem jest utrwalanie dziedzictwa historycznego i kulturowego społeczności osób nieheteronormatywnych, niesiona tym osobom pomoc psychologiczna i prawna, a także działalność kulturalna i edukacyjna w zakresie promowania różnorodności społecznej. Klub Historyczny wszedł więc w struktury fundacji jako istotna jej część, pozostając jednak, z uwagi na rozpoznawalność tej nazwy w mediach społecznościowych, przy swojej pierwotnej nazwie - Klub Historyczny LGBTQIA FEM.

Wedle naszej wiedzy w Polsce nie funkcjonuje żadna inna instytucja, która zajmowałaby się systematyczną archiwizacją materiałów związanych z omawianą tematyką. Klub Historyczny ze względu na przekonanie o konieczności podejmowania w naszym kraju działań ratowniczych

\footnotetext{
${ }^{1}$ Skrót od słów Lesbijka Gej Biseksualna/-y Transpłciowa/-y Queer Interseksualna/-y Interseksualna/-y. Do pierwotnego skrótu LG z czasem, wraz z rozwojem samoświadomości poszczególnych osób i grup zaczęto dodawać kolejne litery.
} 
dotyczących tych materiałów, inicjuje działania archiwalne i muzealne, równocześnie dbając o wypełnianie podstawowych, stawianych Fundacji celów. Za istotne uważamy bowiem dbanie o:

- dostrzeganie istnienia historii społeczności LGBTQIA, nieprzyzwalanie na jej pomijanie, czy marginalizowanie,

- spojrzenie perspektywiczne, czyli pokazanie zmian zachodzących na przestrzeni lat (czy nawet wieków), związanych z „odbiorem” tej społeczności i wskazanie, że zmiany te zachodziły i zachodzą nadal, co najlepiej widać w historycznym ujęciu tematu,

- przychylność, czyli skupianie się na takim ujęciu tematu, które miałoby wpływ na zwiększenie komfortu psychicznego osób LGBTQIA².

Zarówno Archiwum, jak i Muzeum są odpowiedzialne za wypełnianie tak nakreślonych celów, co zostało wspólnie w Klubie oraz Fundacji przedyskutowane i wprowadzone jako zasada komunikacji ze społeczeństwem.

Muzeum jak do tej pory nie ma fizycznej siedziby czy stałych wystaw, a prezentuje zbiory kolekcjonerskie związane ze społecznością LGBTQIA, ale także z ruchami feministycznymi. Wynika to $\mathrm{z}$ faktu, że w tych ruchach działa niemało osób określających się jako lesbijki, biseksualistki.

Przed podjęciem decyzji o powołaniu wirtualnego muzeum, podjęliśmy się zorganizowania trzech stacjonarnych wystaw czasowych. Pierwsza miała miejsce w siedzibie Feminoteki i odbyła się w tygodniu „paradowym”, w czerwcu 2017 r., a jej celem było przedstawienie aktywności różnych organizacji i grup LGBTQIA, działających w latach 90. na terenie całej Polski. W listopadzie 2017 r., w ramach współorganizowanej wraz z Monarem konferencji skierowanej do osób zajmujących się pomaganiem ludziom wykluczonym, stworzyliśmy „ścianę pamięci” mówiącą o współpracy Monaru i organizacji LGB w czasach pandemii AIDS. Obecnie niewiele osób o tym pamięta, dlatego wydało się nam istotne, by przywrócić pamięć o tej współpracy i o jej efektach. Wystawa prezentowana była podczas Konferencji „ONI? WY? MY”, organizowanej przez Monar (24-25 listopada 2017 r.). Fundacja Q była w tym przypadku partnerem społecznym. Ostatnią była wystawa uliczna, zorganizowana 10 listopada 2018 r. z okazji 100-lecia odzyskania Niepodległości przez Polskę i przedstawiała postaci historycznie uznawane za osoby homoseksualne, wskazując tym samym, że i one działały

\footnotetext{
${ }^{2}$ Kampania Przeciw Homofobii co kilka lat wydaje raport związany z sytuacją osób LGBTA w Polsce https://kph.org.pl/wp-content/uploads/2015/04/Sytuacja-spoleczna-oso\%CC \%81b-LGBTA-w-Polsce-raport-za-lata-2015-2016.pdf, data odczytu: 29.06.2020.
} 
na rzecz odzyskania niepodległości. Wspominała między innymi autorkę Roty - Marię Konopnicką. Niestety, po mniej więcej 20 minutach ekspozycja została usunięta przez nieznane osoby, po prostu zniknęła z ulicy.

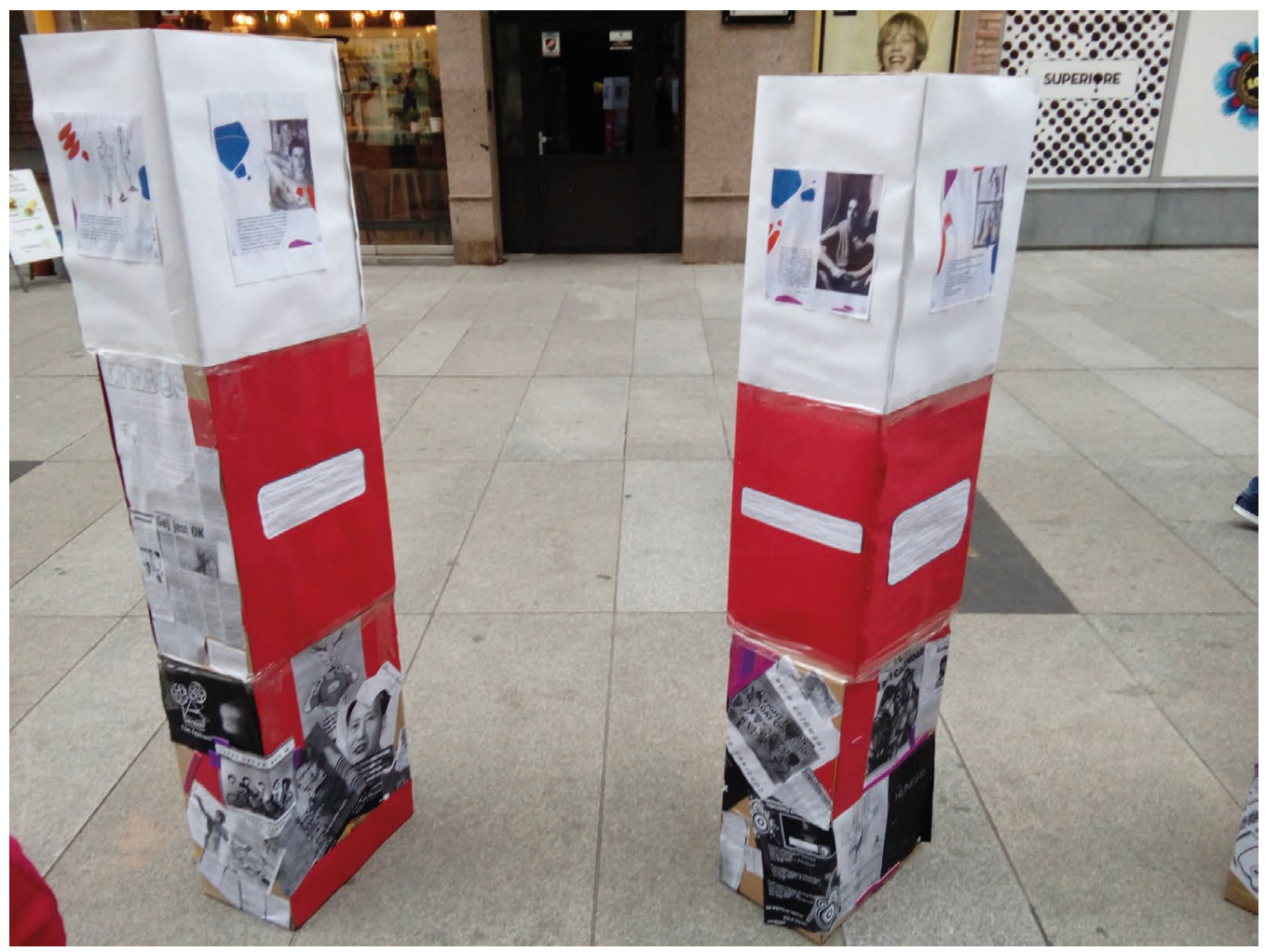

Il. 1. Wystawa uliczna z okazji 100-lecia odzyskania niepodległości 10 listopada 2018 r. (Fot. Kamil Prykowski)

Pomysł na utworzenia wirtualnego muzeum pojawił się już pod koniec 2017 r., ale samo muzeum powstało 6 czerwca 2018 r. Termin zainicjowania działań muzeum został wybrany w nawiązaniu do tygodnia wydarzeń związanych z Dniem Parady w Warszawie. Tym, co nas przekonało do wirtualnej formy, była jej względna trwałość i możliwość przekazania głównej idei każdego z pokazów. Wcześniej organizowane wystawy po zamknięciu prezentacji nie pozostawiły śladu dokumentującego tak myśl główną jak i przesłania, a dokumentacja fotograficzna ograniczała się jedynie do przedstawienia ogólnego widoku prezentowanych plansz. Obecnie w wolnym dostępie do obejrzenia są trzy wirtualne wystawy, Postrs of Polish LGBTQI organizations, After „Hiacinth”-Filo oraz After „Hiacinth”-game ${ }^{3}$.

${ }^{3}$ https://artsandculture.google.com/partner/foundation-q, data odczytu: 29.06.2020. 
Pierwsza z nich przedstawia plakaty promujące działania różnych polskich organizacji LGBTQIA ${ }^{4}$. Dbając o estetyczną stronę prezentacji, staramy się przekazać jak najwięcej informacji o różnorodności działań podejmowanych przez organizacje istniejące na terenie całej Polski. Wystawy spotykają się z zainteresowaniem i odzewem sympatyków z całego świata, dzięki nim ludzie mogą dowiadywać się o zakresach i charakterze polskich aktywności w obszarze LGBTQIA. Niekiedy spotyka się to z odzewem, na przykład dostaliśmy informację zwrotną od Enrique Alpanesa ${ }^{5}$, dziennikarza z gazety hiszpańskiej, w której doceniono działania podejmowane w Polsce.

\section{POSTERS OF POLISH LGBTQIA ORGANIZATION}

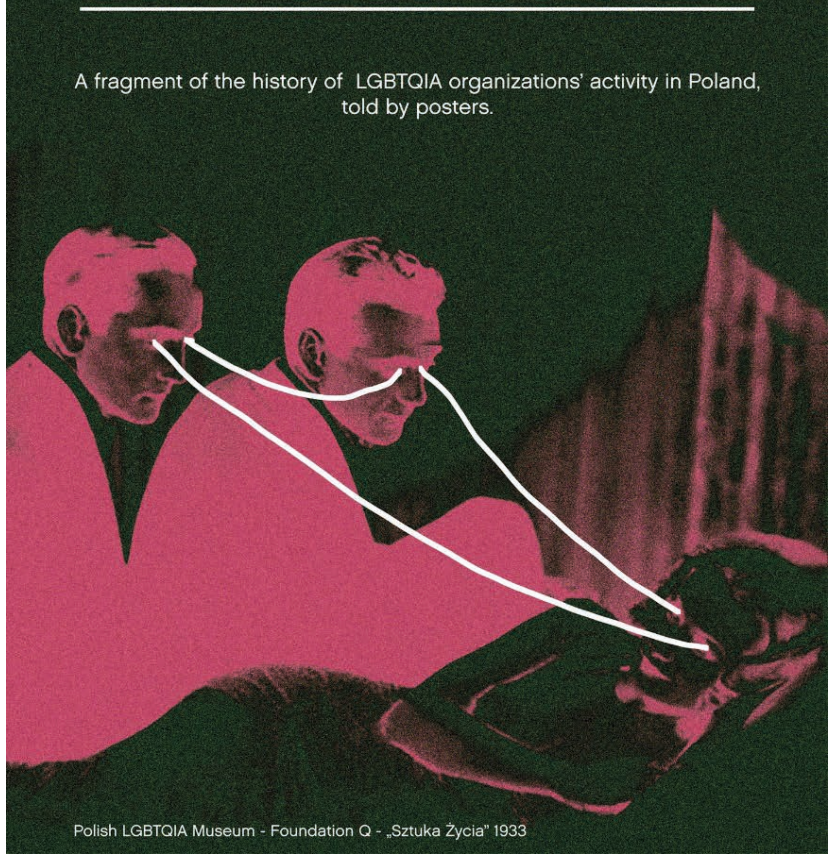

Il. 2. Nowy plakat filmu Sztuka Życia przygotowany przez Klub historyczny w ramach zaangażowania Fundacji Q w reklamowanie 9. LGBT Film Festiwalu w 2018 r. Autorka: Zuzanna Charkiewicz

\footnotetext{
${ }^{4}$ https://artsandculture.google.com/exhibit/posters-of-polish-lgbtqia-organizations/EAIi RhONWFjZLw, data odczytu: 03.08.2020.

${ }^{5}$ https://www.yorokobu.es/museo-lgtb-polonia/, data odczytu: 03.08.2020.
} 
Kolejna wystawa to After Hiacinth - Filo, jest opowieścią o Akcji Hiacynt. Były to zorganizowane w latach 1985-1987 w całej Polsce działania Milicji Obywatelskiej, skierowane przeciw gejom. Byli oni zatrzymywani, zmuszani do zeznań, często funkcjonariusze MO poprzez zastraszanie doprowadzali do tego, że niektóre osoby ujawniały tożsamość innych osób o homoseksualnej orientacji. Zatrzymanym zakładano akta osobowe, czyli tzw. różowe teczki. Każda z nich mogła stać się materiałem do szantażu tych osób i zmuszania ich w przyszłości m.in. do współpracy ze Służbą Bezpieczeństwa. W wystawie skoncentrowaliśmy się na wielkim poruszeniu, jakie w środowisku gejowskim wywołała akcja, którą potocznie nazywano „łapanką”, ale także na tym, że stała się ona przyczynkiem do podjęcia prób zorganizowanego aktywizmu. Zależało nam także na tym, by zaprezentować znaczenie „Filo”, czyli pierwszego polskiego magazynu gejowskiego,
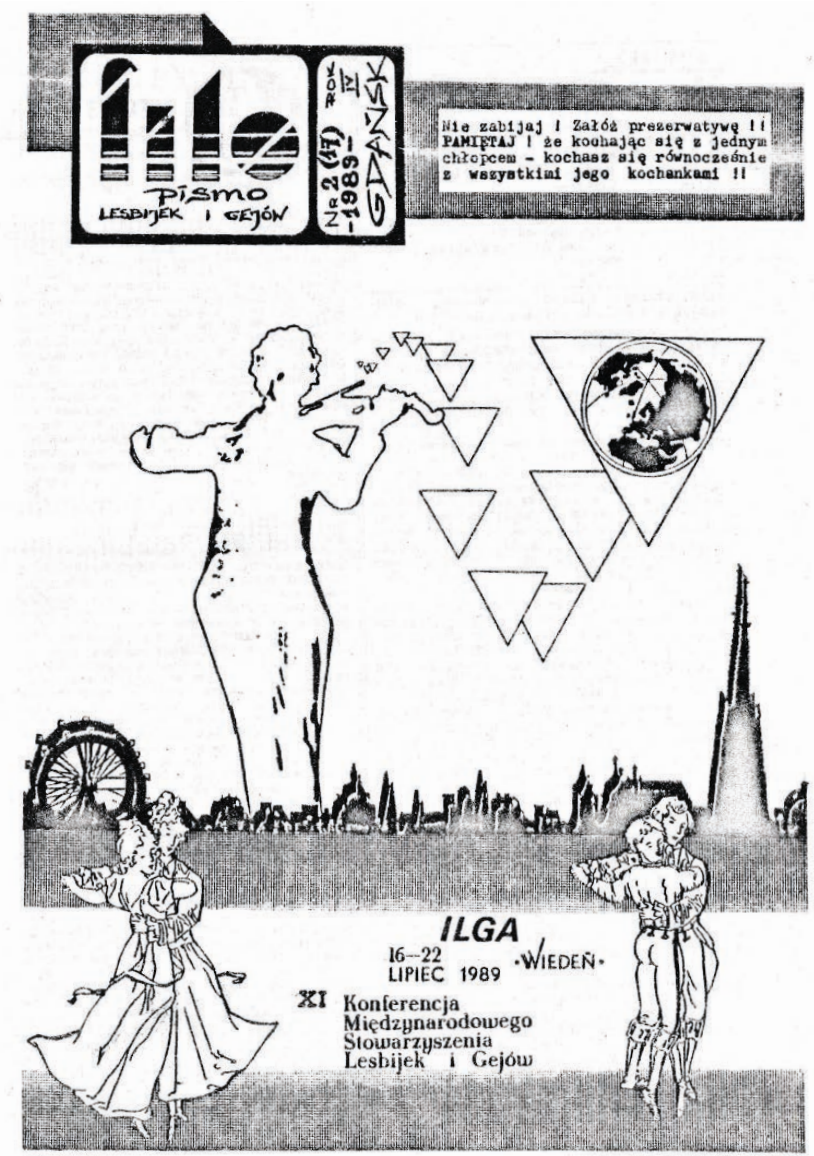

Il. 3. „Filo” jako zin. Archiwum prywatne Ryszarda Kisiela - założyciela „Filo” i redaktora wersji zinowej 


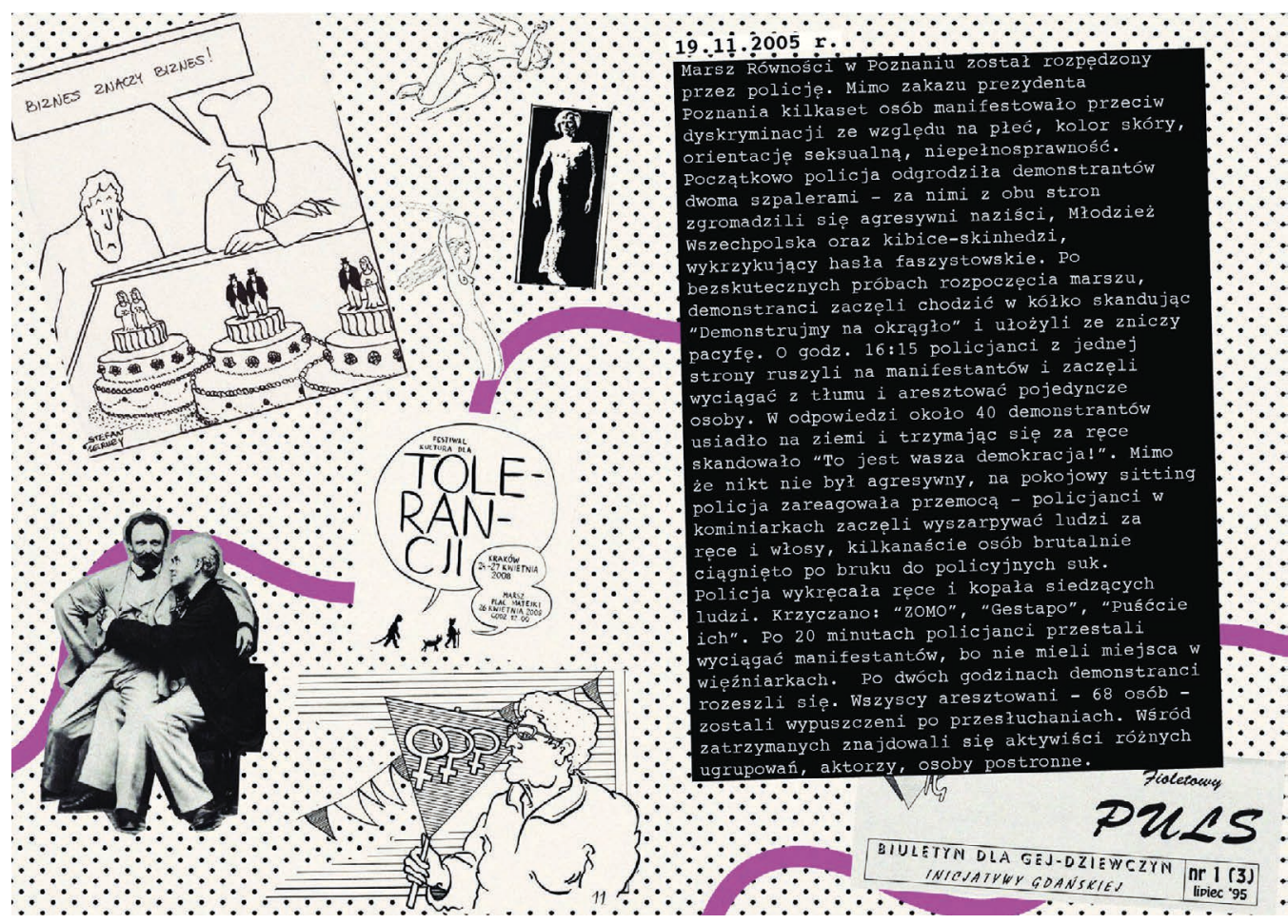

Il. 4. Fragment zina towarzyszącego grze Akcja Hiacynt. Archiwum Klubu historycznego LGBTQIA Fem

który pierwotnie po Akcji Hiacynt wychodził jako zin6 , a następnie, od 1990 r., jako regularny miesięcznik. Na tej wystawie umieściliśmy również fragment nagrania filmowego z Ryszardem Kisielem, pierwszym redaktorem tego magazynu. Film pochodzi z zasobów archiwalnych prowadzonej przez nas dokumentacji wspomnień środowiska LGBTQIA.

Ostatnia wystawa nosi nazwę After Hiacinth — game ${ }^{7}$. Ekspozycja związana jest z wydarzeniem, jakie miało miejsce w trakcie trwania organizowanych w Warszawie Dni Różnorodności, podczas których Klub Historyczny Fundacji Q, przy wsparciu młodzieży gimnazjalnej, zorganizował grę miejską dotyczącą Akcji Hiacynt. W jej ramach powstał zin zawierający treści historyczne oraz poruszający kwestie mające znaczenie dla edukacji antydyskryminacyjnej. W grze mógł wziąć udział każdy mieszkaniec/mieszkanka Warszawy, a wystawa jest dokumentacją tego wydarzenia.

Działania Klubu Historycznego LGBTQIA FEM oraz Fundacji Q od początku były związane z aktywizmem LGBTQIA i ukierunkowane na rozbu-

\footnotetext{
${ }^{6}$ Zin (fanzin) — rodzaj nieprofesjonalnego pisma tworzonego przez pasjonatów.

${ }^{7}$ https://artsandculture.google.com/exhibit/after-hyacinth-game/YQJSFmFU92CXJQ, data odczytu: 03.08.2020.
} 
dzenie i rozwój samoświadomości tej grupy mniejszościowej. Jak wynika z raportów publikowanych przez Kampanię Przeciw Homofobii ${ }^{8}$, istotnym problemem dla osób ze społeczności LGBTQ jest brak przekazu i możliwości skorzystania z doświadczeń przeszłych pokoleń. Osoby LGBTQ nie mają ani w środowisku rodzinnym, ani szkolnym, przekazów związanych ze swoją orientacją/tożsamością i każdy/a z członków/członkiń musi z tym uporać się osobiście, a to oznacza, że samotnie muszą mierzyć się z tematem własnej tożsamości, poszukiwaniem odpowiedzi na pytanie: „kim jestem”. W związku z tym osoby przynależne do społeczności LGBTQIA odkrywające swoją tożsamość/orientację, zazwyczaj doświadczają jej znacznie bardziej boleśnie niż ich rówieśnicy. Z tych powodów, bardzo ważne jest poszukiwanie grupy, w której ludzie ci znajdą zrozumienie i akceptację.

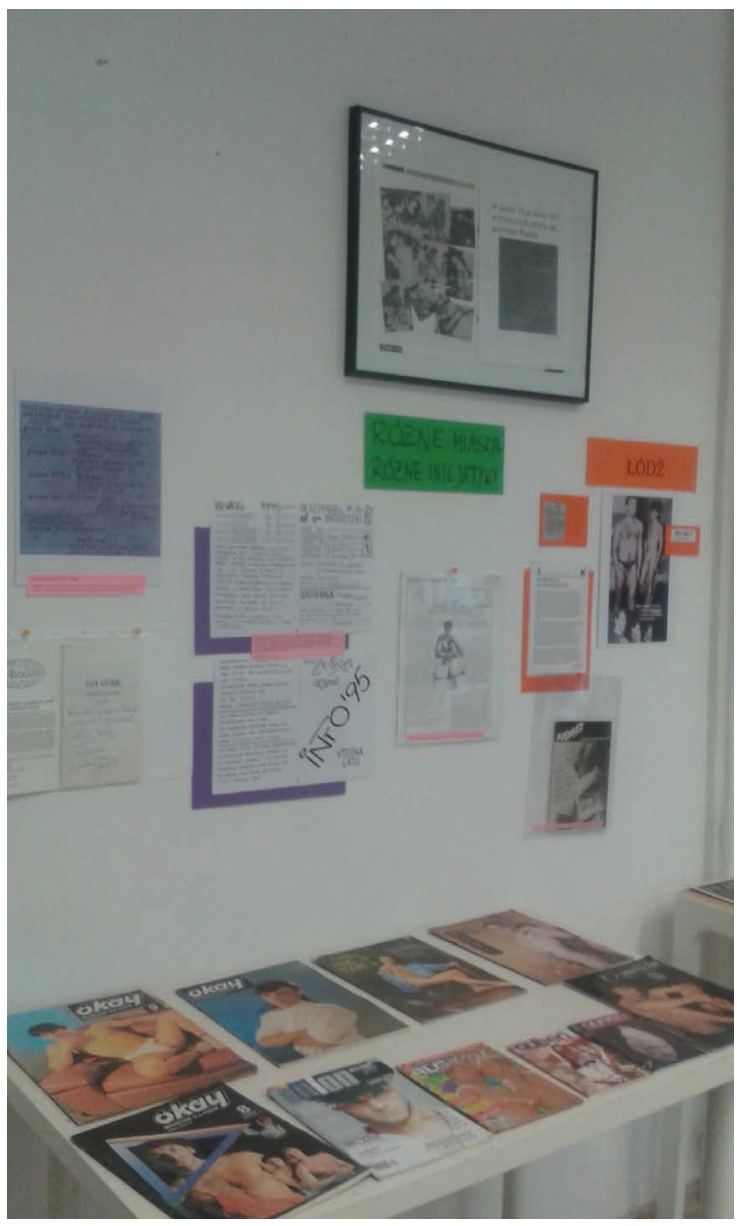

Il. 5. Fragment wystawy w siedzibie Feminoteki z okazji tygodnia paradowego, 3 czerwca 2017 r. (Fot. Agnieszka Wiciak)

\footnotetext{
${ }^{8}$ Kampania Przeciw Homofobii co kilka lat wydaje raport związany z sytuacją osób LGBTA w Polsce: https://kph.org.pl/wp-content/uploads/2015/04/Sytuacja-spoleczna-oso\% CC\%81b-LGBTA-w-Polsce-raport-za-lata-2015-2016.pdf, data odczytu: 29.06.2020.
} 
Z naszej perspektywy znaczące jest, aby w ten proces poszukiwania indywidualnego i grupowego włączyć historię ,jako narzędzie służące poznaniu własnej tożsamości. Człowiek jest istotą, która może w pełni zrozumieć siebie między innymi dzięki przynależności do grupy i znajomości historii własnej, wpisanej w historię grupy [Paczkowska-Łagowska 2012: 73]. Znajomość historii, rozpoznanie barw i odcieni życia oraz działań ludzkich podejmowanych w przeszłości bywa zaskakująca i intrygująca, ale pozwala niekiedy na zbudowanie poczucia bliskości i więzi z dawnymi grupami. Poczucie związków i bliskości z postaciami historycznymi może być pomocne w tworzeniu poczucia sensu własnego życia, orientacji i tożsamości, a dzięki poczuciu ciągłości trwania pewnych wartości pozwalać na odnalezienie pewności siebie. Sądzimy również, że znajomość historii może pomóc w uporaniu się z zarzutami o „wymysł ostatnich czasów” rodzaj „nowomody”, czy wręcz... ideologii, jak próbuje się dzisiaj przedstawiać problemy osób LGBTQIA.

W związku z powstaniem archiwum Fundacji Q ogłosiliśmy Manifest historyczny, który jest dla nas wyznacznikiem i przyświeca nam, wskazując kierunki działań podejmowanych w odniesieniu do historii. Został on upubliczniony na stronie Facebooka: Klub Historyczny LGBTQIA FEM, a po powstaniu wirtualnego muzeum również na jego stronie internetowej ${ }^{9}$.

Zbiory archiwalne są zwykle „ukryte” w archiwach i bardzo zależy nam na ich udostępnieniu. Dzięki temu pokazujemy, że dbamy o to, abyśmy nie byli zmarginalizowani i uwidoczniamy jednocześnie fakt, że na społeczność LGBTQ można spojrzeć szerzej niż tylko poprzez jej seksualność. Jest to jedno z tych działań, które pokazuje nasze życie, znajdując w nim dużo pozytywów, np. liczby działań i inicjatyw; pokazuje też pary z długoletnim stażem związkowym. Takie ujęcie wpływa na dobrostan osób, na ich lepsze funkcjonowanie społeczne i osobiste, a wszystko to z bezpiecznej historycznej już odległości. Ważne jest, abyś zobaczyła/ł, jaki nastąpił postęp na przestrzeni lat w odbiorze osób LGBTQ przez społeczeństwo - a jest to zazwyczaj mało widoczne, dopiero retrospektywne spojrzenie pozwala to zobaczyć w pełni. To z kolei ma wpływ na przekonanie o skuteczności działań, jakie są podejmowane na rzecz osób LGBTQ oraz na zwiększenie nadziei na jeszcze lepszą przyszłość. W obecnej sytuacji politycznej to działanie (jak jedno z wielu) będzie dawało poczucie, że robimy coś

\footnotetext{
${ }^{9}$ https://www.facebook.com/historiaLGBTQ, data odczytu: 17.08.2020. Manifest obec-
} nie znajduje się w zakładce Informacje na stronie naszego Facebooka. 


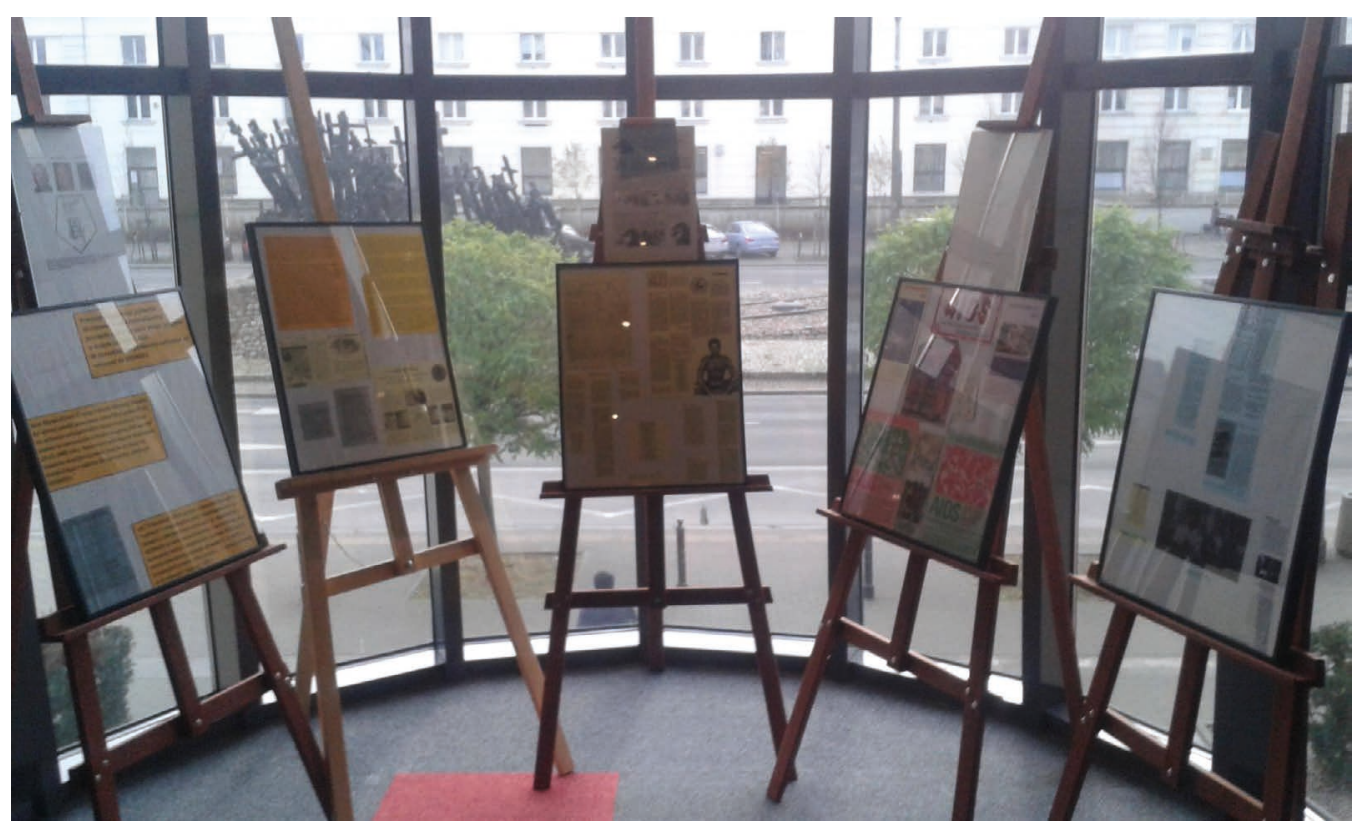

Il. 6. Ekspozycja upamiętniająca współpracę Monaru i organizacji LGB w czasach pandemii AIDS, listopad 2017 r. (Fot. Agnieszka Wiciak)

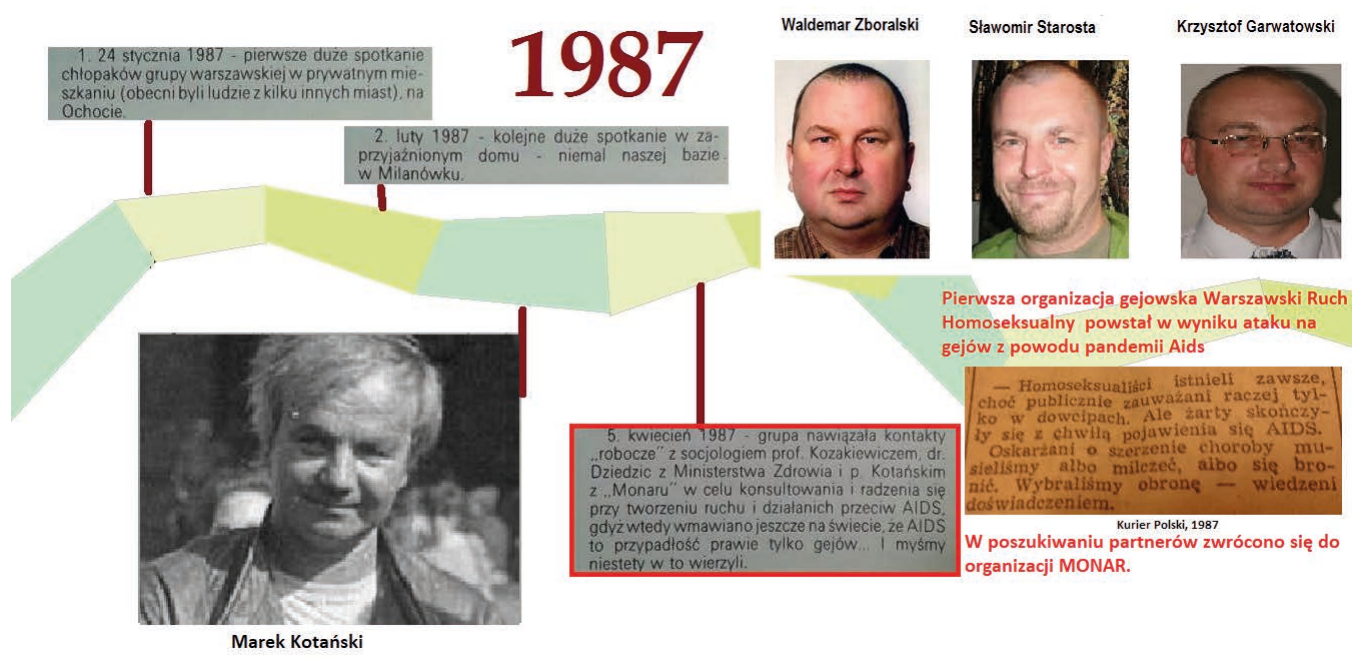

Il. 7. Fragment ekspozycji upamiętniającej współpracę Monaru z organizacjami LGBT w czasach pandemii AIDS. Na zdjęciu Marek Kotański i założyciele Warszawskiego Ruchu Homoseksualnego. (Fot. Agnieszka Wiciak) 
dobrego i stajemy „po dobrej stronie”. Jednocześnie nie jest to działania konfrontacyjne w założeniu.

Powstanie muzeum było wynikiem ewolucji naszych działań związanych z aktywizmem. Pierwotnie najistotniejsze wydawało się nam utworzenie archiwum, czyli stworzenie bazy materiałów oraz nagrań świadków i świadkiń historii. Interesowały nas szczególnie lata 1986-2000, bowiem mniej więcej od 2000 r. Internet stał się na tyle dostępny i popularny, że zaczął wypierać prasę. W tym czasie osoby LGBTQIA zaczęły rozwijać różne aktywności właśnie w przestrzeni internetowej, gdzie są one archiwizowane niemal automatycznie.

Z drugiej strony należy zauważyć, że ludzie w miarę upływu czasu w sposób naturalny prowadzą selekcję posiadanych przedmiotów. Przeprowadzki, remonty lub generalne sprzątanie stają się okazją do tego, by rozstać się z rzeczami nieużytecznymi. Ideą przewodnią naszego muzeum jest zachowanie pamiątek minionego czasu, powstrzymanie ludzi przed wyrzucaniem ich na śmietnik. Wierzymy, że muzeum, którego zbiory są dostępne online, uwiarygadniają nasze działania i pozwalając dotrzeć do wielu osób, które — być może — będąc w posiadaniu materiałów z lat 80.i 90. XX w. zechcą się nimi z nami i innymi ludźmi podzielić. Dzięki obecności w Internecie otrzymaliśmy cztery przesyłki z materiałami archiwalnymi, pośród nich znalazł się między innymi list (Fot. 8):

Dzięki naszym działaniom mamy nadzieję na uniknięcie sytuacji, w której zabrakłoby źródeł historycznych do wiedzy o społeczności LGBTQIA w latach 1986-2000. Jesteśmy przekonani, że jeżeli materiały z tego czasu nie zostaną zdigitalizowane, to zwyczajnie przestaną istnieć, gdyż nasze doświadczenia i wiedza wskazują, że zabiegi konserwatorskie materiałów papierowych związanych ze społecznością LGBTQIA nie należą w instytucjach publicznych do zadań priorytetowych. Na dowód tego przytoczę pewną historię. Jeden z dawnych działaczy, postanowił przekazać część swoich zbiorów do Biblioteki Jagiellońskiej, a część do Schwules Muzeum w Berlinie ${ }^{10}$. Po pewnym czasie zależało mu na skorzystaniu z niektórych materiałów, które trafiły do BJ i zaskoczony dowiedział się, że nie ma możliwości skorzystania z nich lub zeskanowania, ponieważ „nikt nie wie”, gdzie one w tym momencie się znajdują. Okazało się, że nawet nie zostały

\footnotetext{
${ }^{10}$ https://www.schwulesmuseum.de/, data odczytu: 03.08.2020. Schwules Muzeum to założone w 1985 r., muzeum, które specjalizuje się w historii i kulturze gejów oraz ruchu emancypacyjnego w Niemczech.
} 


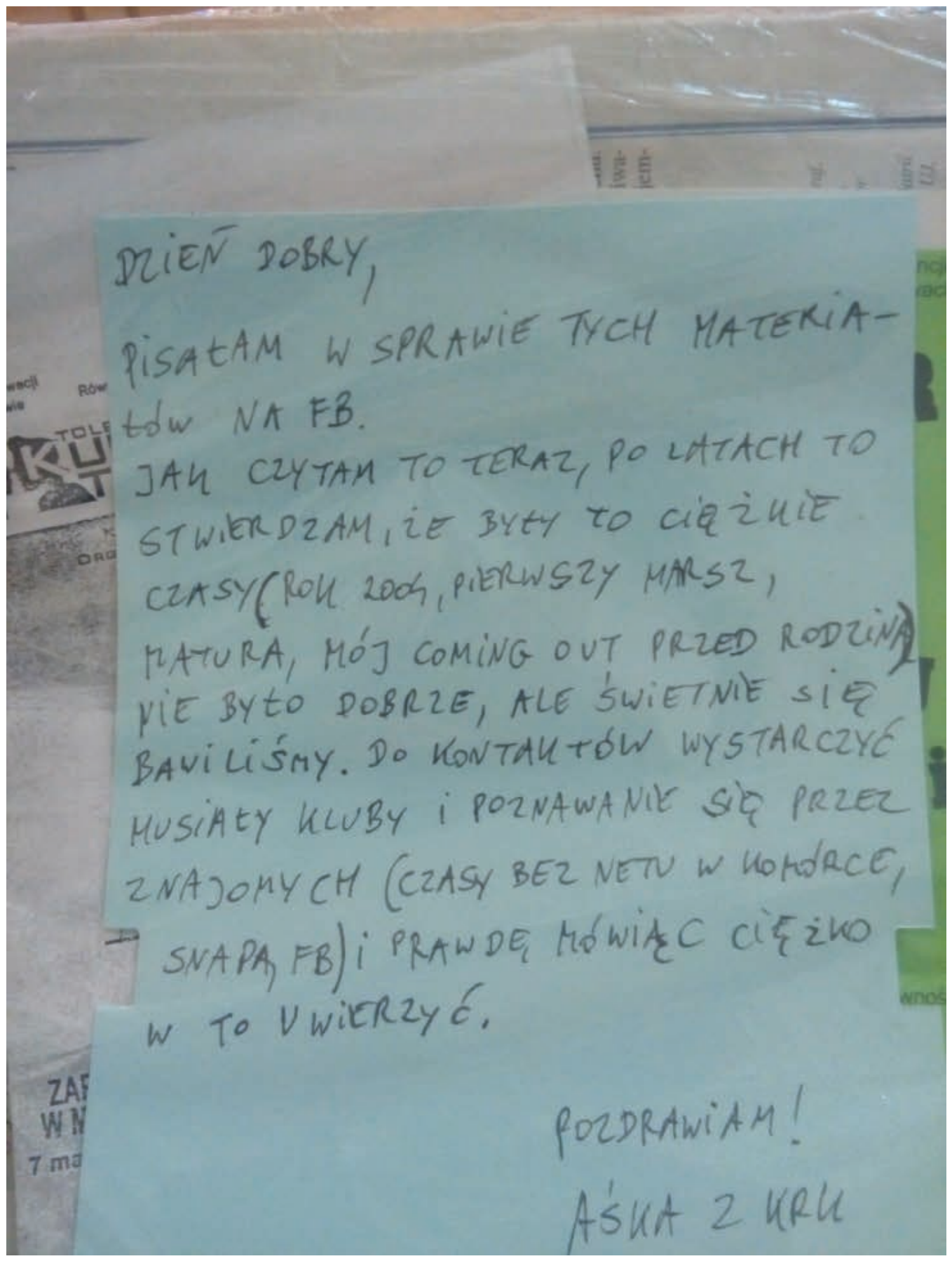

Il. 8. List od Aśki z Krakowa, która przekazała do archiwum Klubu historycznego LGBTQIA Fem materiały związane ze społecznością LGBTQ 


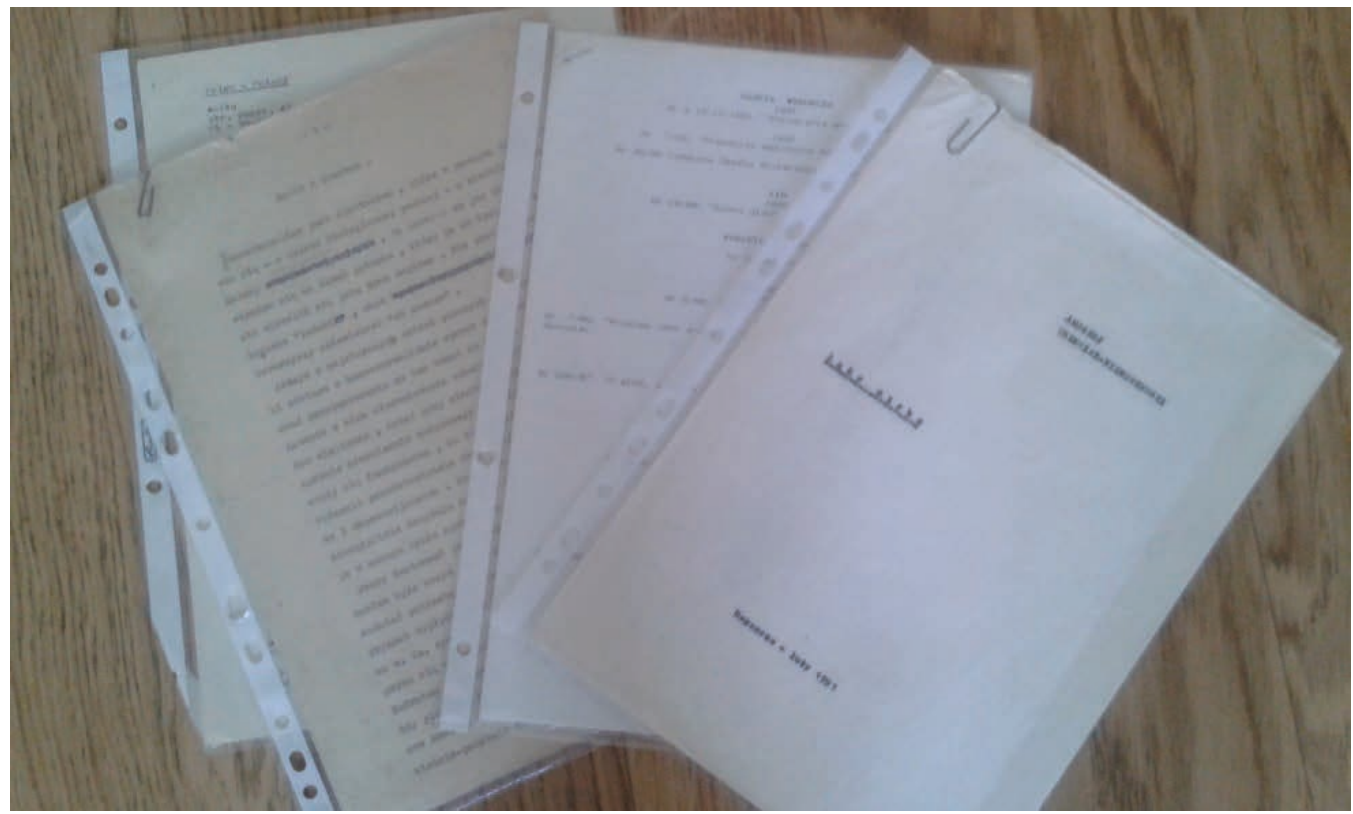

Il. 9. Materiały z wyprawy pod Lublin - niepublikowane wiersze, arykuły do publikacji w gejowskich gazetach, lista działaczy/czek (Fot. Agnieszka Wiciak)

zewidencjonowane. W takiej sytuacji trudno właściwie powiedzieć, co się z nimi stało i co się stanie w przyszłości11.

Warto dodać, że podczas pracy zauważyliśmy, jak wiele się teraz dzieje i jak szybko te działania stają się przeszłością, nieopisaną historią. Uznaliśmy więc, że nasze archiwum, z którego czerpiemy materiały do muzeum, powinno zająć się również uzupełnianiem materiałów z działań czasowo nam bliższych. Miejscem docelowym umieszczenia całości archiwaliów jest platforma archiwów społecznych tworzonych przez Ośrodek Karta (osa.archiwum.org), na którym mamy już swoje konto i obecnie jesteśmy w trakcie skanowania materiałów.

O tym, jak ważne są nasze działania „ratownicze”, świadczy pewna historia. W 2017 r. spotkaliśmy się z działaczem z lat 90. XX w., który mieszkał wówczas we wsi „na końcu Polski”, w naprawdę trudnych warunkach. Kiedy się z nim skontaktowaliśmy telefonicznie, pan wyraził zadowolenie, że chcemy przyjechać, nagrać wywiad i zabrać materiały, ponieważ właśnie zastanawiał się, co z nimi zrobić. Zastanawiał się, czy ich nie... zakopać!

\footnotetext{
${ }^{11}$ Informacja od anonimowego rozmówcy. Nagranie z wywiadu znajduje się w naszym archiwum
} 


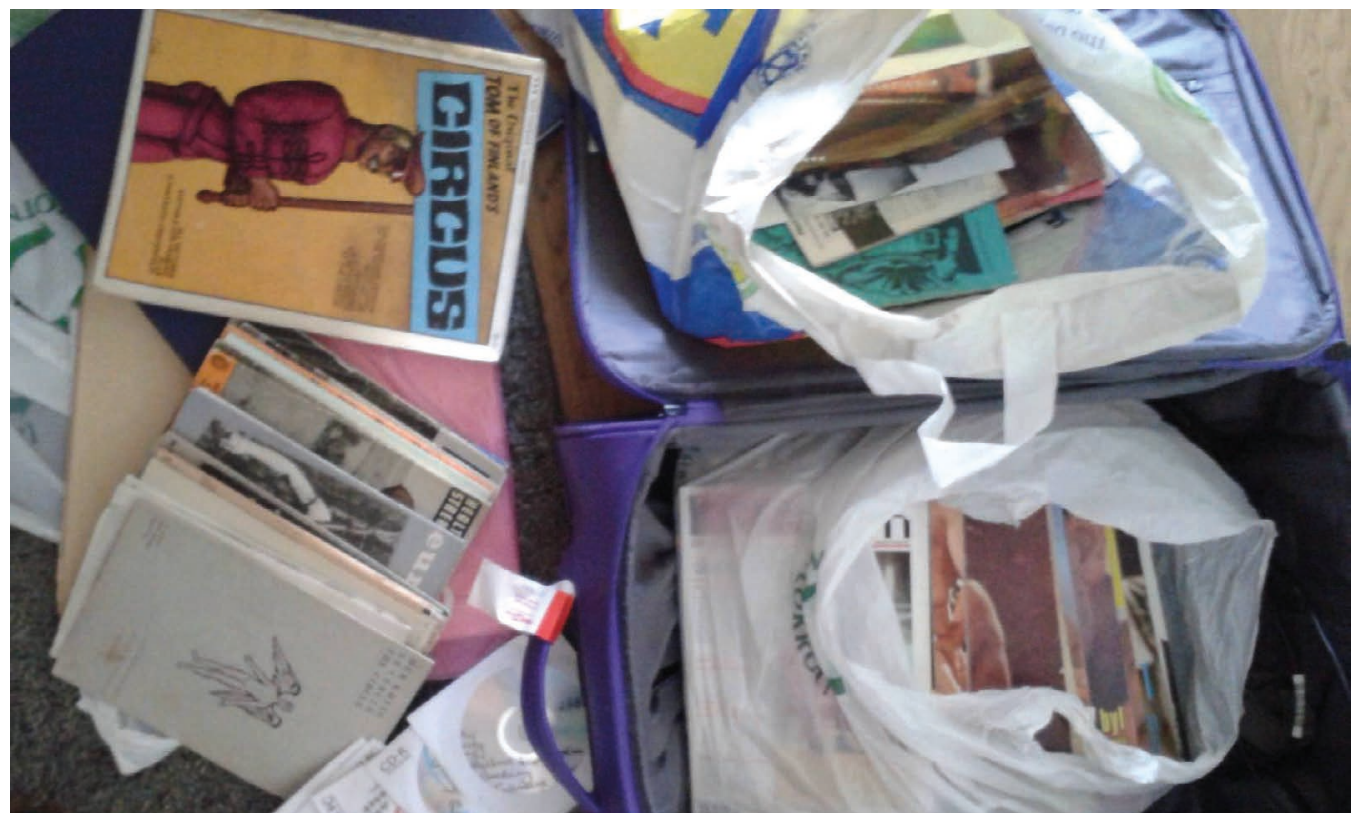

Il. 10. Materiały z jednej z wypraw do Wrocławia - gazety np: prasa gejowska, „Tom of Finland” (Fot. Agnieszka Wiciak)

Dodam, że był on przewodniczącym pierwszej zarejestrowanej po $1989 \mathrm{r}$. organizacji - Stowarzyszenia Grup Lambda ${ }^{12}$.

Właśnie przy okazji nagrywania wywiadów udaje się zdobyć najwięcej nowych eksponatów z lat 90. XX w. W takich sytuacjach pojawiają się przeróżne materiały, których charakter zależy głównie od osoby, z którą rozmawiamy. Istotne jest, czy rozmówca był aktywnym działaczem, czy nie. Niektóre z tych archiwaliów są bardzo cennym źródłem wiedzy o historii. Są pośród nich przeróżne materiały: od kaset wideo, książek, prasy polskiej, zagranicznej, po komiksy, ziny, druki ulotne, dokumentacje organizacji, listy, wiersze. Zamieszczony tu materiał ilustracyjny pochodzi ze zbiorów Fundacji Q.

Podczas zbierania archiwaliów nagrywamy historie osób, do których udaje nam się dotrzeć. Zależy nam przede wszystkim na tych, którzy w latach 90. $\mathrm{XX}$ w. aktywnie zajmowali się działaniami w ramach powstających wówczas organizacji czy grup nieformalnych skupiających osoby LG. Obecnie mamy dwadzieścia nagrań, które stanowią ważne dopełnienie zbiorów.

Ponieważ muzeum to nie archiwum, bardzo ważna jest forma, w jakiej coś upublicznimy i tutaj stajemy zazwyczaj przed większymi wyzwania-

\footnotetext{
${ }^{12}$ Stowarzyszenie Grup Lambda (SGL) pierwsza zarejestrowana organizacja LG, działała w latach 1989-1997. Założycielami byli członkowie nieformalnych grup z Warszawy, Krakowa, Gdańska.
} 


\section{Caic Marek! Nowa Sil, 2595.11 .19}

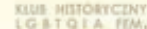

Po dariadoremin meczuilo prosorrego sedu - nekomej wolnota howarkinalistón in Polsue nepaczete sie ortro kampanio precion...

homoseksualistom! Zaczeto rabierac chtopatón

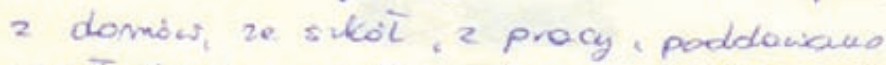
prestuchaniom, zdejmontano oduski palcks, robions adjecio, zaloziono tas "Kanty houraseksuclisty" Po munio prajectwen do procy, cmproesedzonco jako ponestepce Naraiono musie no ktopoty " procy. Usitavano munie szontoziowar, dletego rever upredzitem szefo. is mops by poljate wobec muio proby szantazic dlatepo wole, osdiscie szefa (ondymatona oddiall sipitalugo)

painformo. io jestem homaseksualisto. Szef podziekavot mi 7o zanfanie i zepentuit, ze mio musze sie micaym mantwid Nobchmiost pojechatem do

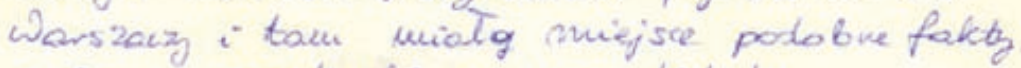
- cram porredrieh mi moi koledy.

Te kezprawno zotineymanio maja sproubdic

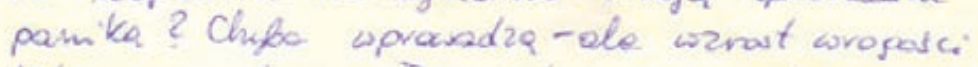
kolejnej warstiry spotecrevistwa procies kornumitom w Polsce.

To tyle no disigj. Pozdraviam wablek Zkadda:

Il. 11. List, w którym Waldemar Zboralski opisuje swoje doświadczenie podaczas Akcji Hiacyt. Archiwum Klubu historycznego LGBTQIA Fem (za zgodą autora). 
mi niż podczas działań archiwalnych. Główną przyczyną takiego stanu rzeczy jest dbałość, by muzeum było przestrzenią przyjazną dzieciom. Wystawy nie powinny więc zawierać żadnych treści erotycznych, gdyż mogłyby stanowić zagrożenie dla osób nieletnich. I jest to bardzo ściśle i rygorystycznie przestrzegane. W zasadzie nie ma możliwości stworzenia wystawy z dopiskiem „tylko dla dorosłych”, ponieważ, jak wiadomo, nie ma możliwości zapewnienia ochrony, by na dane strony nie wchodziły osoby niepełnoletnie. Niesie to za sobą pewne ograniczenia dla tworzenia przez nas wystaw, ale jak zauważyliśmy, jednocześnie pozwala z większą uwagą spojrzeć na nasze materiały i to, w jaki sposób chcemy opowiadać o historii LGBTQIA. Jest to więc wartość dodana.

Także charakter niektórych materiałów uniemożliwia ich prezentację. Trudno jest nam na przykład pokazać część kolekcji zdjęć erotycznych robionych we wczesnych latach 90. XX w. z uwagi na możliwość rozpoznania widocznych na nich osób. Wiąże się to również z koniecznością ochrony wizerunku oraz uzyskania zgody na upublicznienie zdjęć, której nie mamy możliwości otrzymać. Wiemy natomiast, że niektóre z zainteresowanych osób określają się jako heteroseksualne i być może nie chciałyby upubliczniania swoich ówczesnych preferencji i zainteresowań. Podobnie jest ze zdjęciami z lat 80. XX w., na których przedstawieni są radzieccy żołnierze, znani z imienia i nazwiska. Z opowieści starszych gejów wynika, że w koszarach wojsk radzieckich we Wrocławiu można było znaleźć chętnych, którzy za przysłowiową butelkę wódki lub ciuch z PEWEX-u zgadzali się pozować do fotografii. Często autorzy ujęć starali się tym zdjęciom nadać wyraz artystyczny, a tego typu przedstawień można w zbiorach starszych gejów znaleźć całkiem dużo.

Ponadto wystawy o treści erotycznej są problematyczne także z tego względu, że niejako automatycznie powodują, iż środowisko LGBTQIA jest postrzegane jako bardzo rozerotyzowane. Dla niektórych odbiorców ekspozycja taka może być potwierdzeniem ich przekonań na temat tej społeczności. Wiele działań, na przykład parady/marsze równości, wywołują w przestrzeni publicznej dyskusję dotyczącą tych zagadnień. Bywa ona bardzo gorąca i obdarzona niesprawiedliwymi oskarżeniami oraz negatywnymi ocenami, podczas gdy erotyka heteroseksualna jest mocno obecna w otoczeniu (np. reklamy, prasa, agencje, kluby go-go etc.), nie budząc aż takich negatywnych emocji. 


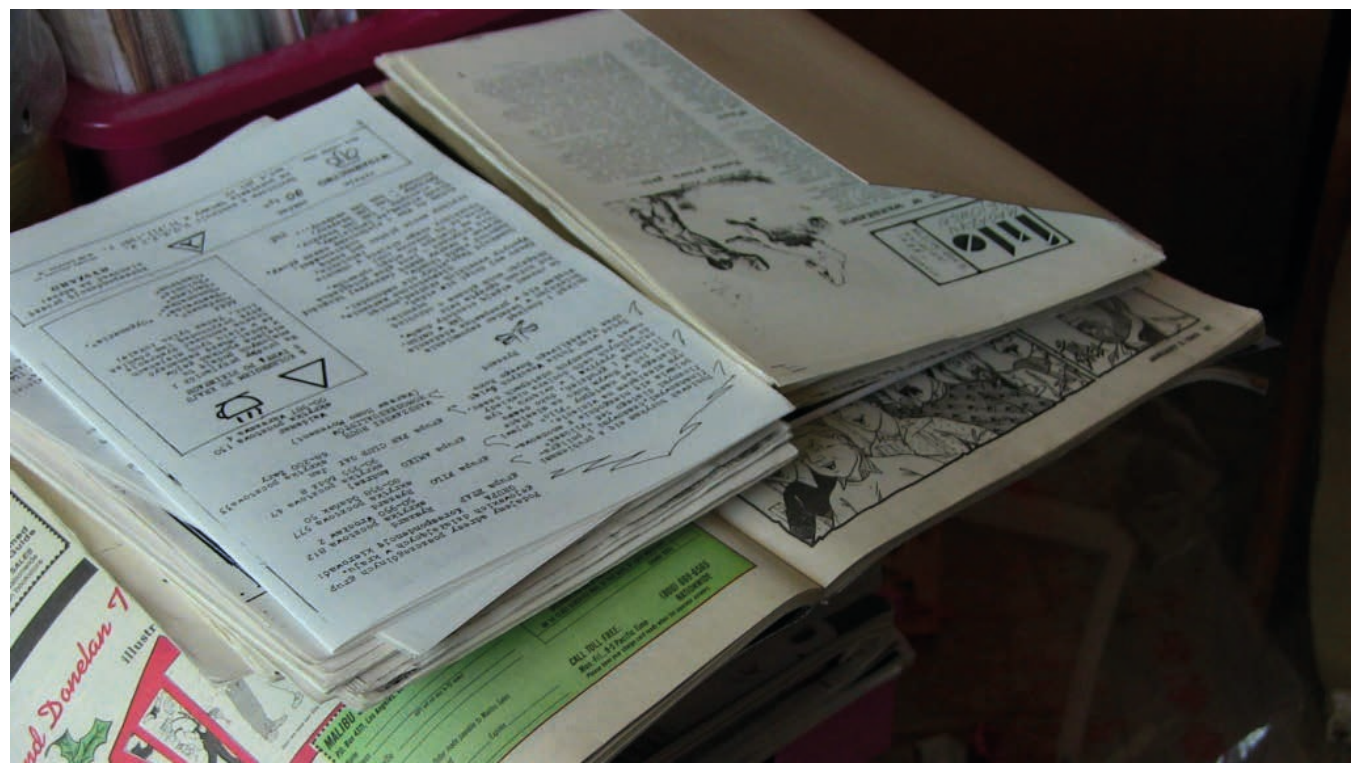

Il.12. Czasem skanujemy materiały na miejscu - ziny „Filo” z wyprawy do Gdańska (Fot. Kamil Prykowski / Agnieszka Wiciak)

Pojawił się w tym miejscu ważny aspekt związany z tym, w jaki sposób osoby (niebędące LGBTQIA) mogą zareagować na wystawę, jak ją zinterpretują, jakie wystawa może u nich wywołać reakcje emocjonalne. Przy tworzeniu archiwum nie wydaje się to aż tak istotne jak właśnie przy tworzeniu wystaw, które wszak są dostępne w domenie publicznej.

W archiwum jest bardzo dużo materiałów (takich jak druki ulotne, dokumenty etc.), które same w sobie nie wydają się w pierwszej chwili aż tak atrakcyjne, ale nabierają wartości po bliższej analizie podjętej przez osoby, które zdecydowały się skorzystać z tych źródeł. Charakter tej analizy może zależeć od sposobu, w jaki użytkownik odbiera i rozumie otaczający świat, czasem bez podejmowania prób zrozumienia motywów, zamiarów czy emocji autorów, które leżą u podstaw powstania tych dokumentów [Maruszewski 2001: 17-18]. Natomiast muzeum dostarcza niejako gotowy „produkt” w postaci danych zaprezentowanych w sposób możliwie zrozumiały i już zinterpretowany. Stawia to zupełnie nowe cele przed naszym muzeum. Dotychczas wystawy były tworzone przy konkretnych okazjach, a ich powodem były wydarzenia społeczne. Równocześnie stanowiły uzupełnienie dla archiwum, reklamując i promując jego zasoby. Obecnie muzeum ewoluuje w stronę bardziej samodzielnego nośnika wiedzy o LGBTQIA, a przygotowania do wystaw i praca wokół nich zasila archiwum choćby 


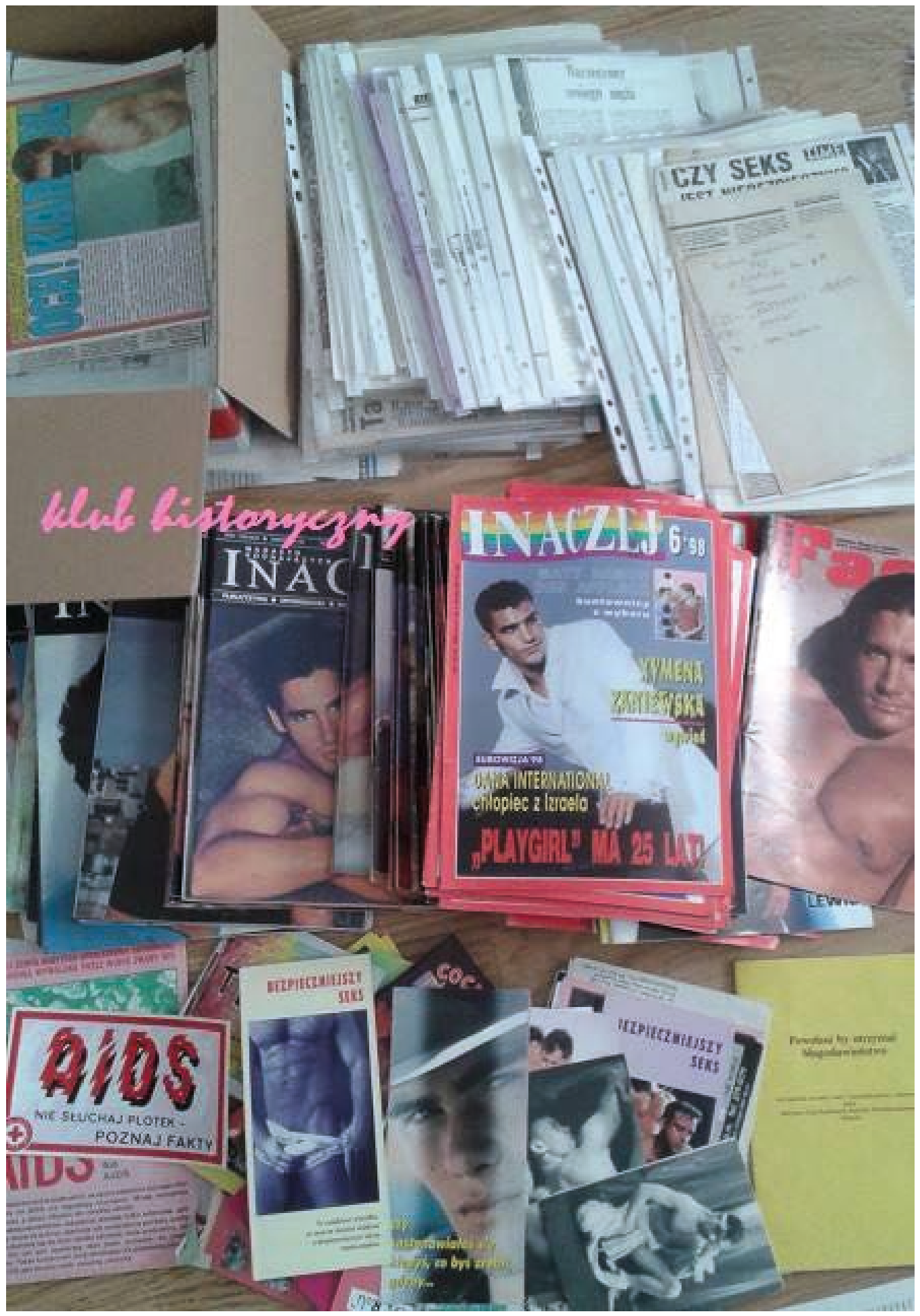

Il. 13. Z wyprawy pod Lublin (Fot. Agnieszka Wiciak) 


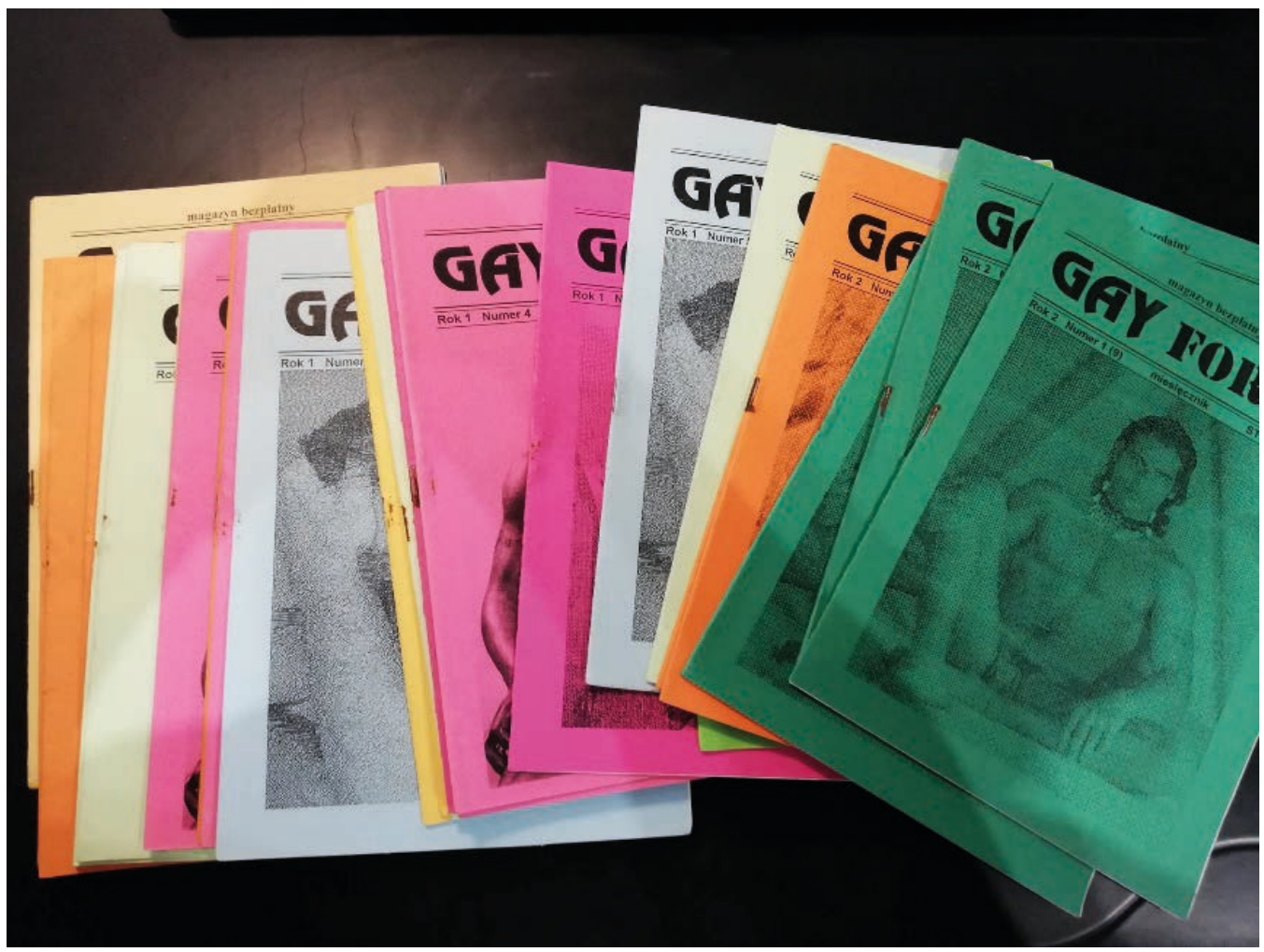

Il. 14. Z wyprawy do Wrocławia - miesięcznik „Gay Forum”, który ukazywał się w latach 1996-1997 (Fot. Agnieszka Wiciak)

poprzez tworzone nagrania. Wirtualne muzeum zachęca wręcz do nagrywania filmów podczas nagrań audio wspomnień osób LGBTQIA. Ponadto wymaga spójnie opowiedzianej historii, czego nie trzeba robić podczas zbierania archiwaliów.

Warto dodać, że materiały związanych z osobami określającymi się jako geje, jest stosunkowo dużo, natomiast trudnością jest dotarcie i zbieranie dokumentów dotyczących działalności prowadzonej przez kobiety. Od różnych osób dowiadujemy się, jak wiele się działo, ale nie można dotrzeć do niektórych działaczek. Dużo mniej jest też materiałów czysto archiwalnych. Wydaje się, że w zachowywaniu historii osób określających się jako lesbijki najważniejsze są nagrania wspomnień. Wszystko wskazuje na to, że wraz z upływem czasu bezpowrotnie zniknie możliwość dotarcia do inicjatyw, wydarzeń czy postaci związanych z lesbijkami.

Muzeum z założenia skierowane jest do wszystkich, również do osób nie związanych ze społecznością LGBTQIA. Informacja o pierwszej wystawie była wysłana do zaprzyjaźnionych archiwów LGBTQIA także poza Polską 


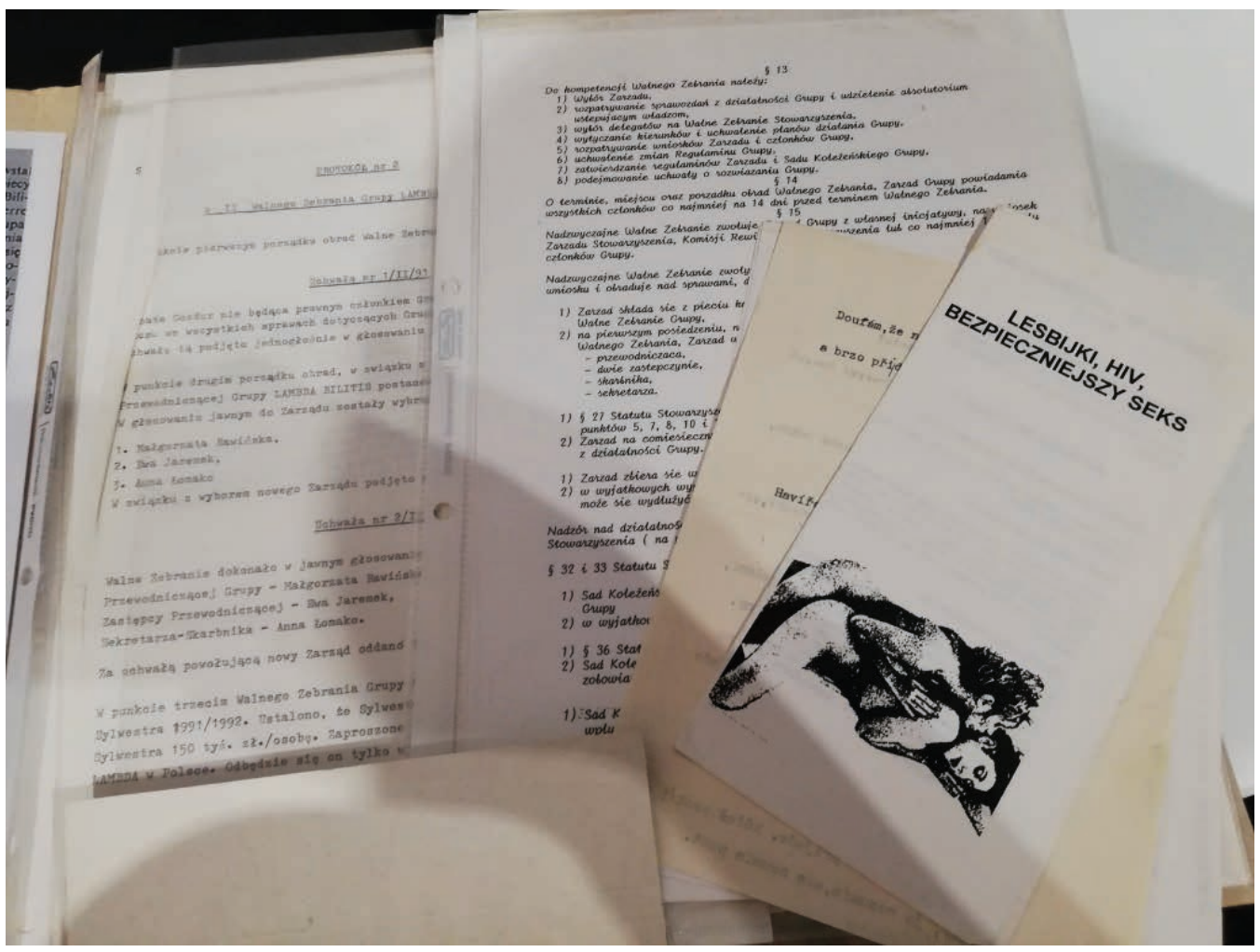

Il. 15. Efekt poszukiwań warszawskich - materiały jednej z nielicznych organizacji lesbijskich Bilitis (Fot. Agnieszka Wiciak)

i właśnie z tego powodu ekspozycje były przygotowane w wersji angielskiej. Obecnie pracujemy nad tym, aby dostępna była również wersja polskojęzyczna. Docelowo chcielibyśmy, aby każda następna wystawa była tworzona w dwóch wersjach językowych (polskiej i angielskiej) i mam nadzieję, że się to ostatecznie uda osiągnąć. Nie ukrywam, że na obu wersjach językowych zależy nam tak samo i cały czas też uczymy się obsługiwać narzędzie, jakim jest aplikacja Google Art \& Culture, z której korzystamy.

Wykorzystywana przez nas platforma prowadzi miesięczne statystyki odwiedzin i zawierają one m.in. informacje następujące: kraj, źródło z którego się korzystało podczas przeglądania (traffic source) oraz z jakich urządzeń (platform) korzystano. W ostatnich latach wyglądało to następująco:

— w 2018 r. (od 06.06.2018 do 31.12.2018) obejrzało wystawę 3530 osób,

— w 2019 r. odwiedziły muzeum 1573 osoby,

— w 2020 r. (od 01.01.2020 do 31.05.2020) 930 osób.

Największa oglądalność była w miesiącu i dniu otwarcia muzeum, 6 czerwca 2018 r., wówczas odwiedziło tę stronę 1916 osób (liczba wejść). 


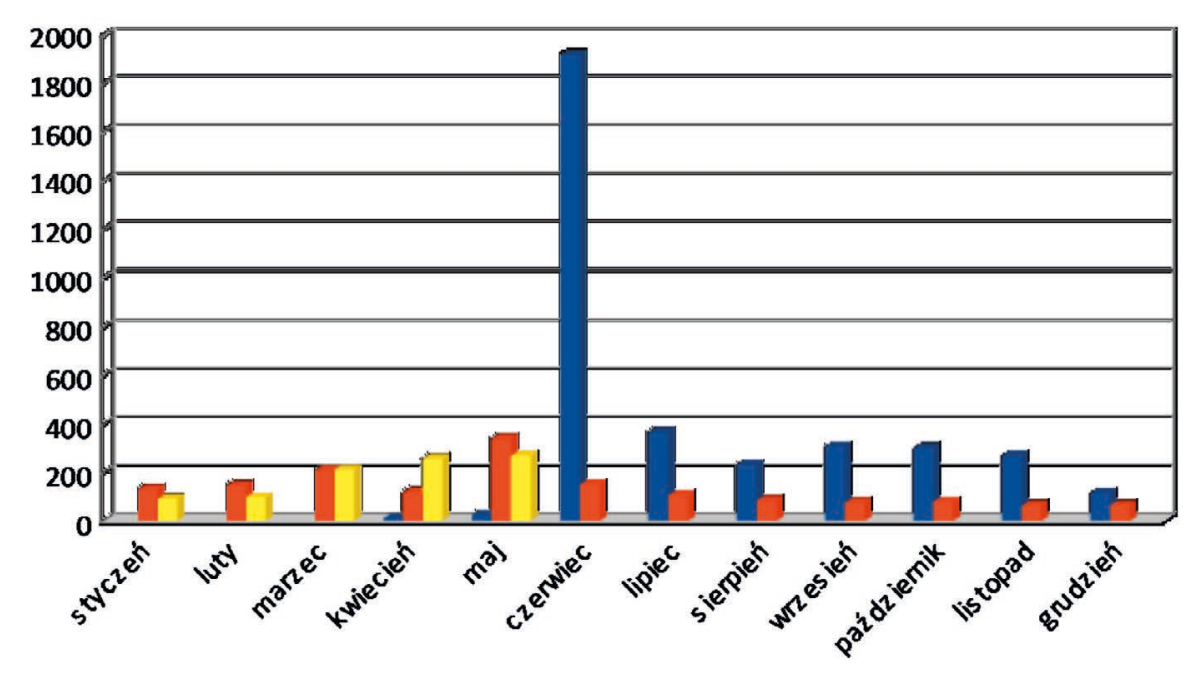

W kolejnych latach, najwięcej osób oglądało wystawy, korzystając z komputera stacjonarnego (web desktop) oraz w telefonach komórkowych. Natomiast źródła, z których czerpano informacje, pochodziły przede wszystkim z bezpośrednich wejść na stronę, poprzez przeglądarkę Google oraz przez Facebook. Jest to zrozumiałe, ponieważ Google reklamował swoją platformę Art \& Culture, natomiast działania reklamowe prowadzone przez Fundację Q wiązały się głównie z Facebookiem. Udzielono również kilku wywiadów w prasie anglojęzycznej oraz hiszpańskojęzycznej, a w Polsce na stronie „Krytyki Politycznej” ${ }^{13}$.

Podsumowując: idea wirtualnego muzeum jest z naszej perspektywy pomysłem trafionym i mającym duży potencjał. Ma moc dotarcia do każdego miejsca w świecie, w którym jest dostęp do Internetu. Pojawiają się próby sieciowania organizacji i osób zajmujących się historią społeczności LGBTQIA. W 2019 r., braliśmy czynny udział w międzynarodowej konferencji ALMS, Queering Memory w Berlinie ${ }^{14}$, która pozwalała na wymianę doświadczeń i informacji wskazujących, w jaki sposób tworzyć muzea i wystawy, w jaki sposób opowiadać, jak promować historię nieheteronormatywną ${ }^{15}$.

\footnotetext{
${ }^{13}$ https://krytykapolityczna.pl/kultura/sztuki-wizualne/muzeum-polski-gejowskiej-i-lesbijskiej/, data odczytu: 03.08.2020.

${ }^{14} \mathrm{~W}$ konferencji wzięli udział przedstawiciele m.in, z USA, Kanady, Tajlandii, Pakistanu, Meksyku.

${ }^{15}$ Więcej o tym wydarzeniu https://queeralmsberlin2019.de/, data odczytu: 03.08.2020.
} 


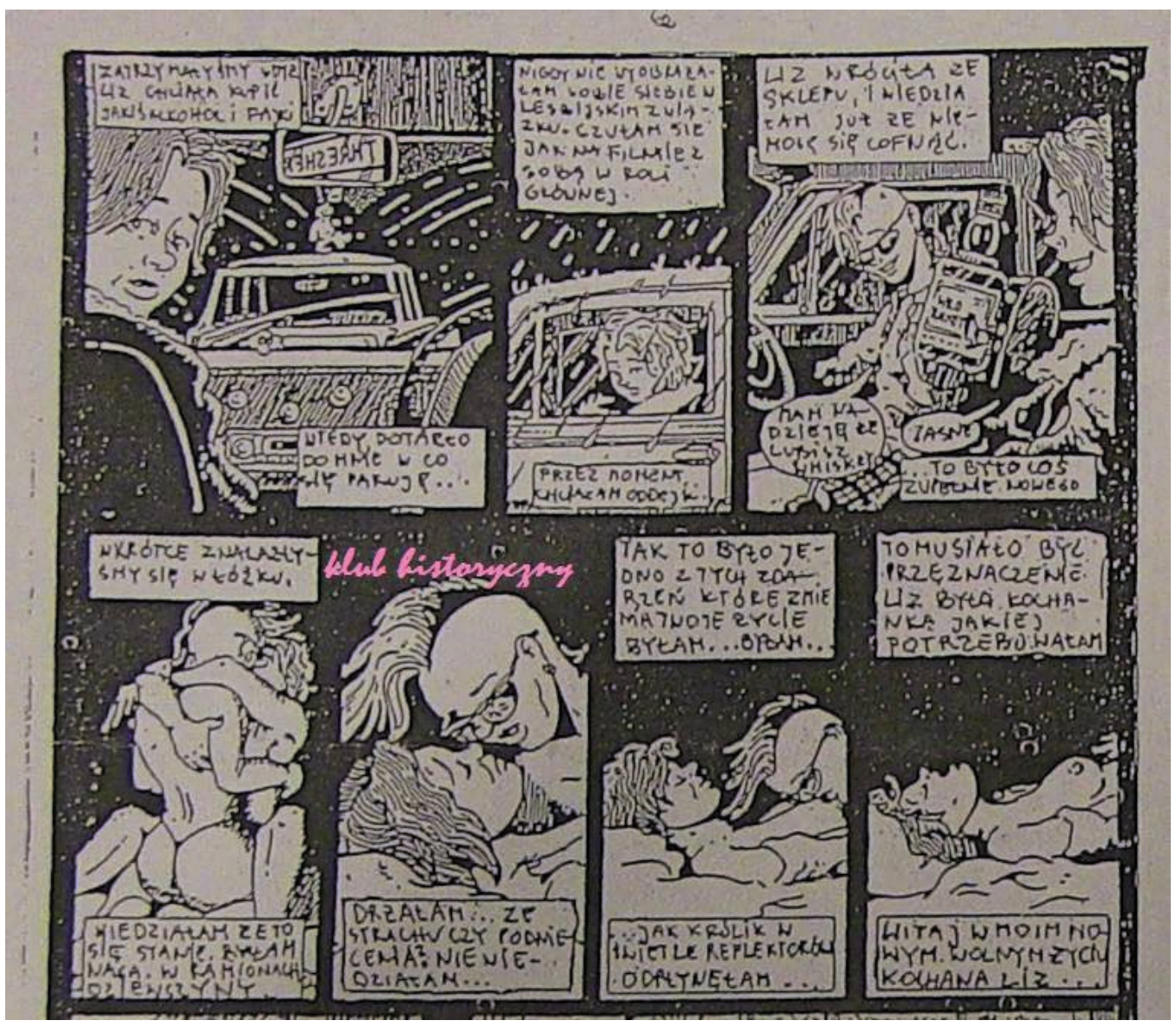

Il. 16. Fragmenty komiksu lesbijskiego (niestety niekompletnego). Dotychczas nie ustalono autorki/a oraz daty powstania. Archiwum Klubu historycznego LGBTQIA Fem 


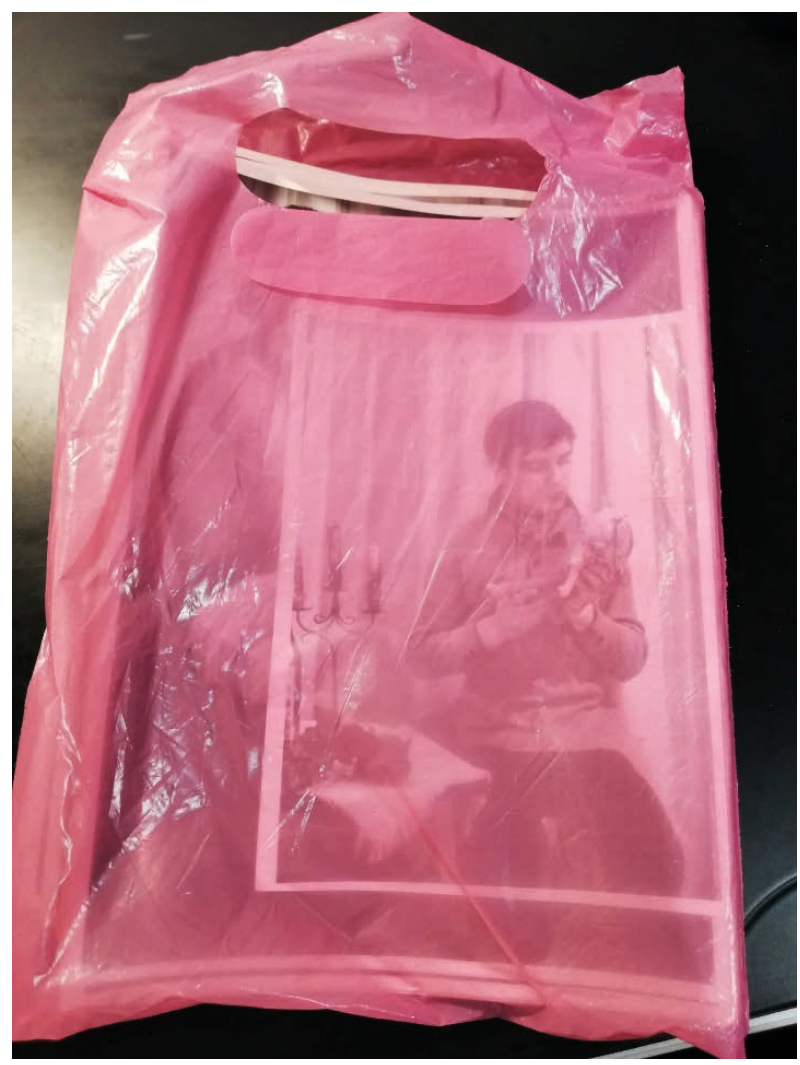

Il. 17. Reklamówka z pozowanymi zdjęciami, lata 80. i 90. XX w. (Fot. Agnieszka Wiciak)

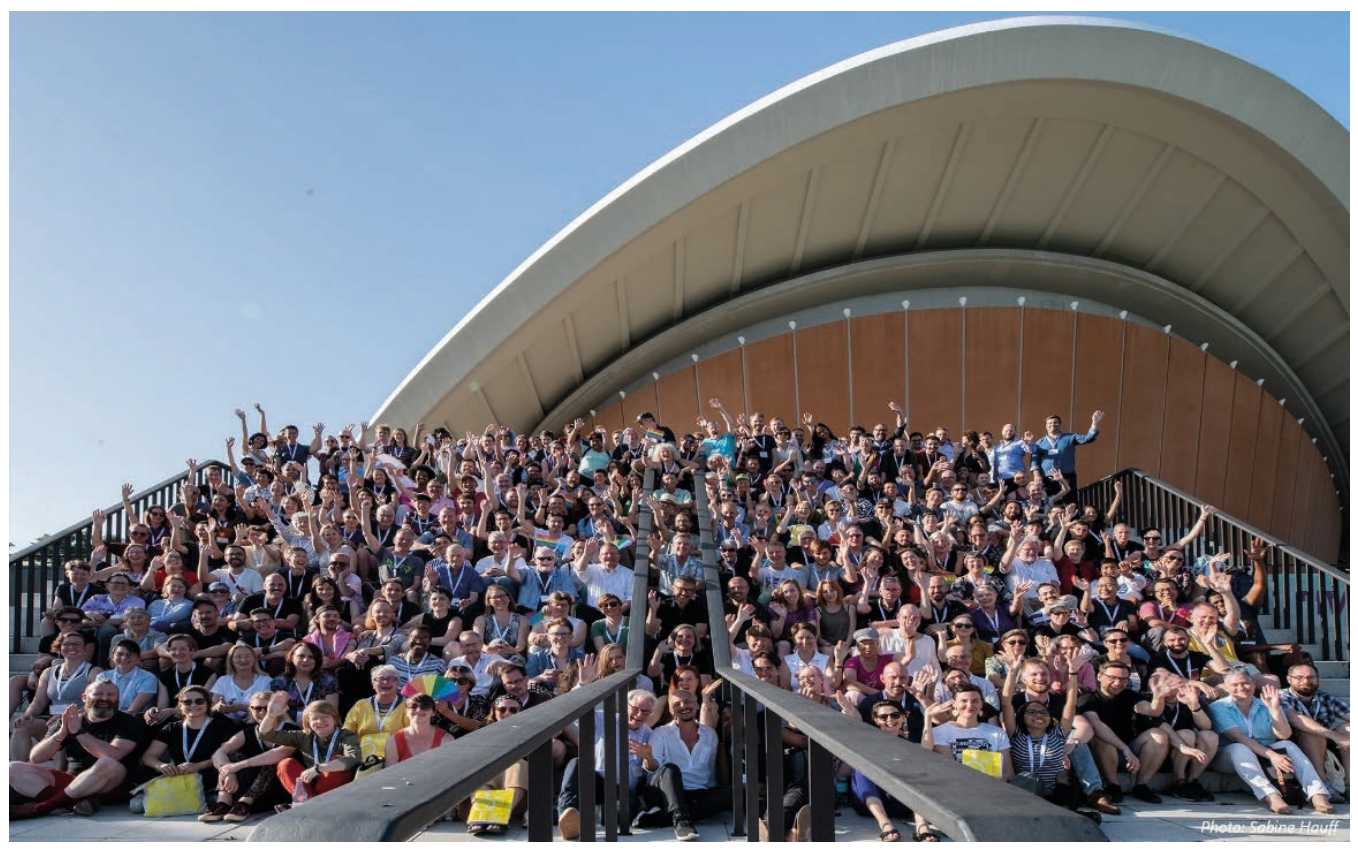

Il. 18. Konferencja ALMS Queering Memory 2019.Źródło: https://queeralmsberlin2019.de/ 
Odsłania się tym samym pilna potrzeba wprowadzenia systematycznych badań nad historią LGBTQIA, nad sposobami jej przedstawiania i upowszechniania. Największą trudnością, którą postrzegamy, jest brak czasu na podróże po kraju wiążące się z działaniami ratowniczymi, a z drugiej strony, na konceptualizację i wykonanie wystaw. Wszystkie te działania są czasochłonne, a nasze muzeum i powiązane z nim archiwum, z którego w dużej części czerpiemy eksponaty do wystaw, funkcjonuje na zasadach wolontariackich. Najpilniejszą więc obecnie kwestią jest angażowanie się w pisanie projektów, które umożliwiłyby nam bardziej systematyczną pracę. Sprawę rozwiązałoby na przykład zatrudnienie większej liczby osób do pracy w terenie, których zadania polegałyby na docieraniu do działaczy i działaczek, zbieraniu archiwaliów, nagrywaniu wspomnień, a w końcowej fazie na tworzeniu wystaw. Bardzo ważnym obszarem działań, które chcemy podejmować, jest prowadzenie badań dotyczących tego, w jaki sposób historia i wiedza o niej wpływają na dobrostan osób LGBTQIA, a także w jaki sposób mogą wpływać na zmianę przekonań osób wrogo nastawionych do tej społeczności. Przy czym należy podkreślić, że nasze działania nie są nastawione na konfrontację. Zależy nam głównie na tym, aby historia LGBTQIA nie była pomijana czy marginalizowana w świadomości Polek i Polaków. Wydaje się, że takie narzędzie, jakim jest wirtualne muzeum, spełnia wymogi tego założenia poprzez to, że wystawy umieszczone w nim są cały czas dostępne, a nie znikają bezpowrotnie, jak to dzieje się w przypadku wystaw czasowych tworzonych w tradycyjnym muzealnictwie.

\section{Bibliografia}

\section{Maruszewski Tomasz}

2001: Psychologia poznania, Gdańsk: Gdańskie Wydawnictwo Psychologiczne.

\section{Paczkowska-Łagowska Elżbieta}

2012: O historyczności człowieka. Studia filozoficzne, Gdańsk: Słowo/Obraz Terytoria.

\section{Strony internetowe:}

https://artsandculture.google.com/exhibit/after-hyacinth-game/YQJSFmFU92CXJQ, data odczytu: 03.08.2020.

https://artsandculture.google.com/exhibit/posters-of-polish-lgbtqia-organizations/ EAIiRhONWFjZLw, data odczytu: 03.08.2020.

https://artsandculture.google.com/partner/foundation-q, data odczytu: 29.06.2020. https://kph.org.pl/wp-content/uploads/2015/04/Sytuacja-spoleczna-oso\%CC\%81b-LGBTA -w-Polsce-raport-za-lata-2015-2016.pdf, data odczytu: 29.06.2020. 
https://krytykapolityczna.pl/kultura/sztuki-wizualne/muzeum-polski-gejowskiej-i-les bijskiej/, data odczytu: 03.08.2020.

https://queeralmsberlin2019.de/, data odczytu: 03.08.2020.

https://www.facebook.com/historiaLGBTQ, data odczytu: 17.08.2020.

https://www.schwulesmuseum.de/, data odczytu: 03.08.2020.

https://www.yorokobu.es/museo-lgtb-polonia/, data odczytu: 03.08.2020.

\section{Agnieszka Wiciak}

\section{Polish LGBTQIA Museum}

The article is a presentation of the virtual museum, which was established on June 6, 2018. It deals with historical topics related to the minority group called LGBTQIA. The museum was established as a consequence of archival activities undertaken by a collecting group called the Historical Club (from 2019 in the structures of the Q Foundation) that from the very beginning was engaged in the rescue operations of archives of the 1990s. Establishing a museum in a virtual form was associated with difficulties in establishing a stationary one and therefore this form of publicity was considered the most appropriate. So far, three virtual exhibitions have been released. The museum and the archive are focused on the goal of incorporating the history of the LGBTQIA community as a tool supporting people who discover or search for their identity and struggle in a painful way with themselves and their surroundings. The purpose of the archive itself is to collect materials unavailable online and which are at risk of irreversible loss, while the role of the museum is to popularize and reach as many recipients as possible. When creating exhibitions, there are many challenges, for example, ensuring that the content is safe for minors. Parallel to archival and museum works, recordings of the oral history of LGBT activists are made. An important issue is how the exhibitions are perceived by the community, not only LGBT but also heteronormative. Although the museum was established as a kind of PR for the archive, now both are fullfledged and have a specific role in the activities of the Historical Club.

Keywords: LGBTQIA museum, virtual museum, history of the LGBTQIA community, Q Foundation 